\begin{tabular}{|lcc|}
\hline & Osmanlı Medeniyeti Araştırmaları Dergisi \\
Journal of Ottoman Civilization Studies & Sayı 12, Nisan 2021 \& No 12, April 2021 \\
C-ISSN 2458-9519 & C2020 Telif Hakkı OSMED'e aittir & Article Types: Research Article \\
\hline DOI: 10.21021 /osmed.789531 & Makale Türü: Araştırma Makalesi & OSMED, 2021, (12): 1-19 \\
\hline Geliş Tarihi \& Received: 02.09.2020 & Kabul Tarihi \& Accepted: 14.11.2020
\end{tabular}

\title{
The Feudal Rule of Mutawila of Jabal Amel under the Ottoman Era 1804-1830 A.D
}

\section{Osama M. Abu Nahel*}

\begin{abstract}
This study deals with the feudal rule of al-Mutawila, a Shiite sect settled in the South of Lebanon, in Jabal Amel under the Ottoman era during the period (1804-1830). Despite the abundance of a great many references on the political and feudal history of the Levant under the Ottoman regime, there remains a large number of issues that have not been tackled by historians. Of these is the history of the Shiite al-Mutawila in Jabal Amel which was eschewed by both Lebanese and non-Lebanese historians in what seems to be a deliberate attempt to ignore historicizing that crucial era in the history of that region of the Muslim World.

The present study is simply a humble effort I have exerted seeking to reevaluate that Muslim sect, in which I stood detached, impartial, and free of any inclinations or prejudices and was urged by a wish that such an effort will ultimately be beneficial to bridging any gaps among the great two Islamic sects; the Sunnis and the Shiites.
\end{abstract}

Keywords: feudal rule, al-Mutawila, Shiites, Jabal Amel, Ottoman era

\section{An introduction}

Despite the many books that dealt with the political and feudal history of the Levant during the Ottoman era, there are many important issues that historians did not stop at, especially the history of the Shiites, or what they were called "al-Mutawila" in the Jabal Amel region, whether these historians are Lebanese Or non-Lebanese, and this neglect is almost intentional - as this will be explained in the course of the research.

It seems that historians of the Shiites in Lebanon, especially in the last century, have begun to become aware of the historical library's lack of references on the history of Jabal Amel, and have begun to rewrite their history anew with a new historical vision that is sometimes not without objective fanaticism, and poured their vengeance on Lebanese historians who differ in their sect or religion. For ignoring the history of their area's events.

\section{The importance of studying}

Writing in the history of the Shiites or dealing with Jabal Amel is very difficult, given the lack of historical references that the researcher can rely on. Therefore, the task becomes more difficult when the researcher collects his information from the few fragments found in the basic references that dealt with the modern history of Lebanon in general, the most important of which is the works of Prince Haidar Ahmed Al-Shihabi, the important one, whose books were not without fanaticism about his ruling family

\footnotetext{
* (Prof. Dr.); Al Azhar University-Gaza (Palestina), Faculty of Arts and Human Sciences, Department of History, osamabunahel@hotmail.com; ORCID: orcid.org/0000-0003-0154-7908
} 
in Mount Lebanon (the Shihabite family), and the persecution that this family-directed against the Shiite community in the Jabal Amel region.

The importance of writing in the history of al-Mutawila in Jabal Amel stems from the often deliberate, or sometimes unintentional, shortcomings of contemporary Sunni historians, who have ignored - and still ignore - the approach to the historiography of that important and vital region of the Islamic world. So; I was encouraged in a humble attempt to uncover the history of that region during the Ottoman era. What encouraged me and pushed me to this step as well, is that during my preparation for my Master's and Doctoral degrees, I found that these people had suffered a lot of injustice on the part of the Ottoman rulers. Then this is; A humble attempt, which I hope will be repeated by the rest of the researchers, to restore respect to these people, regardless of sectarian or political affiliation, as writing history requires stripping away from affiliations.

Accordingly; The importance of the study stems from the fact that it is a study that deals with the role of the Shiites in southern Lebanon during the Ottoman era in establishing a kind of autonomy, as it will serve the study of contemporary history and political science in the Arab world when they study the role of this sect later on, and its impact on all components of Lebanese society.

\section{The study Problem}

Observing the role that the Shiite community took in the Jabal Amel region, or what is called today in southern Lebanon, it is incumbent upon it to confront the policy of containment and sectarian abuse against it during the Ottoman era, it is noted that Arab studies lacked such studies, except for some studies conducted by researchers Lebanese Shiites. The study problem is represented in the following question: What is the role of feudal rule for Jabal Amel during the Ottoman era during the period from 1804-1830 $\mathrm{AD}$ ?

\section{Objectives of the study}

The study aimed to clarify the following:

1. Presenting a geographical historical overview of Jabal Amel before 1804 AD.

2. Explaining how to reconcile between Suleiman Pasha and al-Mutawila and the beginning of the second feudal government.

3. Talking about the development of the relationship between al-Mutawila and Abdullah Pasha.

\section{Study Approach}

This study relied mainly on the descriptive and analytical method, while not neglecting the historical method and narrating its events, to show the most important events in the history of Jabal Amel, as there is no actual or practical value to analyze historical events about which the reader does not know anything without recounting them, and if I tried - as much as possible - that Be summarized.

\section{First: A geographical historical overview of Jabal Amel before 1804 AD}

Jabal Amel, a small part of the land of Lebanon, called southern Lebanon today. Some historians attribute Jabal Amel or Amlah to the Qahtaniyah Amlah tribe, which settled in the Levant after the flood of al-Aram, and landed near Damascus, which was called by the name Jabal Amel about their tribe ${ }^{1}$. And almost all opinions agree that the origin of the inhabitants of Jabal Amel is Yemeni ${ }^{2}$. Lammens ${ }^{3}$ confirms

\footnotetext{
${ }^{1}$ Mohsen al-Amin, Jabal Amel Plans, $1^{\text {st }}$ Edition, Edited by Hassan al-Amin, Beirut: The International House for Printing, Publishing, and Distribution, 1983, p. 51.

2 Muhammad Jaber al-Safa, History of Jabal Amel, $2^{\text {nd }}$ Edition, Beirut: An-Nahar Publishing House, 1981, pp. 33-49.

${ }^{3}$ Lammens (S.J.), La Syrie Précis Historique, Vol. 2, Beyrouth, 1921, p. 182
} 
that al-Mutawila in the Levant, although they belong to the Twelver Shiite Imami sect, they are originally from purely Syrian elements. In other words, they did not mix with other foreign elements.

The Jabal Amel region was known during the Ottoman era as "Bilad Bishara"4, then "Bilad alMutawila" , after this title was given to the owners of the Shiite sect in it. Jabal Amel is divided into eight sub-districts, each of which has villages governed by a single ruler. Four of them are located in the southern section, namely: Mount Hunin or Hunin sub-district and it's center Bint Jbeil, Mount Tibnin or Tibnin district with its center are Tibnin, the coast of Qana and its center in Qana, a Ma'raka coast whose center is Tire, and the latter two in the coast of Tire. And four of them are in the northern part of it, and they are al-Shuqif district and its center, Nabatiyeh, al-Shomer district, its center, Ansar base, al-Tuffah district, its center, Jaba', and Jezzine district, whose center is Jezzine ${ }^{6}$. The total area of Jabal Amel is three thousand kilometers, and its inhabitants believe in Islam according to the Shiite Imami doctrine (Twelvers), including a small number of Sunni Muslims on the coasts, and several Christians in the interior ${ }^{7}$.

Al-Mutawila, or Amelites, in Jabal Amel, were divided into three large groups. There are Banu Saab in the province of Chouf, and Banu Munkar in the province of Shomer and al-Tuffah, and Bani Ali alSaghir in the country of Bishara. They enjoyed self-rule under the leadership of their sheiks, and their submission to the High Porte was nothing more than a reduction in the annual tax imposed on them from the Amiri money. ${ }^{8}$

After the Ottomans subjected Syria to their influence in $1516 \mathrm{AD}$, they divided it into Eilats (Provinces), each of which is governed by a minister (Vali) whose authority does not exceed the cities of the coast and some inland cities, while the rule inside the country remained feudal ${ }^{9}$. The fiefdoms ${ }^{10}$ in the Syrian states have been divided into small plans, administered by a prince, a Muqaddam, or a sheik from ancient or influential families ${ }^{11}$, who is obligated to pay the taxes due on them to the treasury of the Ottoman Sultanate that does not interfere in the affairs of the fiefs, and is only interested in collecting the tax imposed on it according to the system The obligation in effect at that time ${ }^{12}$, or the so-called

\footnotetext{
${ }^{4}$ Bilad Bishara: It is bordered to the north by the Litani River, which separates the country of Bishara and from Shuqif, and to the south by the current al-Qarn River, north of Tarshiha and south of the village of al-Zeeb, and on the west, the Mediterranean coast, and east of Hula and Hasbaya in Wadi al-Taym and the edge of the Bekaa' country. And Bishara of this area attributed to him is unknown, and the family of Ali al-Saghir ruled Bishara's country.

al-Amin, op. cit, pp. 132-133.

${ }^{5}$ Al-Mutawila: which is taken from loyalty, which is love, for the loyalty of the Shiites, the people of the Prophet's house. It seems that the title of the Shiites with this title in Jabal Amel did not advance from the twelfth century of the Hijra, as it began to appear in the year $1100 \mathrm{AH}$, and the Lebanese in the north used to say "Mutawila", and the Palestinians in the south said "Bani Mutual". Muhammad Kurd Ali, Khotat al-Sham, Vol. 6, Damascus, 1925, pp. 352-353; Ali al-Zein, In Search of Our History in Lebanon, $1^{\text {st }}$ Edition, Beirut, 1973, p. 166.

6 al-Amin, op. cit, pp. 135-131.

7 al-Safa, op. cit, p. 24.

8 Mikhail al-Sabbagh, The History of Sheikh Zahir al-Omar al-Zaidani, published and commented: Constantine al-Basha alMukhlesi, Harissa, 1935, p. 11; Ibrahim al-Awrah, History of the Wilayat of Suleiman Pasha al-Adil, published and commented on: Constantine al-Basha al-Mukhlesi, Sidon, 1936, p. 111; Charles - Roux (F.), Les Echelles des Syrie et de Palestine au XV III Siècles, Paris, 1928, p. 207.

9 al-Safa, op. cit, p. 74.

10 The term feudalism is a derivative of the fief and means granting the right to own only the produce of the land. And in the Ottoman era, the feudal lords were called muqataqiyah (plural muqataqi). The feudal rule was hereditary for the most appropriate, senior, or mandarin in the family.

Muhammad Kazim Makki, Intellectual and Literary Movements in Jabal Amel, 2 ${ }^{\text {nd }}$ Edition, Beirut: Dar al-Andalus for Printing, Publishing, and Distribution, 1982, p.88.

${ }_{11}$ Anonymous author, the disclosure of the Nakbat al-Sham, $1^{\text {st }}$ Edition, Cairo, 1895, p. 28.

12 Hani Farhat, The Ameli Trio in the Renaissance, Beirut: The International House of Printing, Publishing, and Distribution, 1981, pp. 25-26.
} 
commitment or guarantee system. These families controlled vast areas of land, in which the peasants worked in exchange for a part of the harvest, while the other part was neither an abscess nor an Amiri, but rather the money of the feudal lord, which became his right based on the commitment he paid ${ }^{13}$.

Feudal feudalism in the Levant, especially in Lebanon, existed before the Ottomans took it over, and it was often of a sectarian character ${ }^{14}$. This type of feudalism was in Lebanon more firmly rooted and stronger than government feudalism ${ }^{15}$.

The Shiites in Lebanon knew this kind of commitment, whether in Jabal Amel in the south or the northern part of the Bekaa' Valley, as well as Kesrouan around the cities of Baalbek and Hermel in the north, with a radical difference between the two regions. Jabal Amel was able to provide a stable model of rainforest farming, as its community was stable, dominated by a class of prominent landowners who wielded their feudal power vigorously overall farmers. In contrast to the northern Bekaa', which was characterized by a lack of stability and agriculture, considering that it is the aridest region of Lebanon ${ }^{16}$.

In any case, Jabal Amel, like other Syrian Provinces, was subject to the contracting system, and many global feudal families took turns over its rule, which were directly and hierarchically subordinated to the governor of Mount Lebanon Province, whether he was from the Ma'ani or Shihabite families, or they were subject to the governor of Damascus, or the Sanjak of Jerusalem, or Acre. Feudal rule continued in Jabal Amel between 1516-1865 AD, with a period of interruption following the coming of Ibrahim Pasha's campaign to Syria in $1831 \mathrm{AD}^{17}$.

There is a difference that distinguished Jabal Amel from other districts. The feudal rule in it was at that time a purely national rule, during which the patriotic spirit grew, strong bonds of solidarity intensified, harmony prevailed among its leaders, and it prevented the Ottoman Sultanate from interfering in their internal affairs. The tax collection in Jabal Amel was completely different from what was happening in the other provinces and countries. The ruler of the mountain did not collect taxes twice or three times in a single year ${ }^{18}$, but only once, or if we may say: The tax collection from the people was in Jabal Amel, done with a kind of mercy and not burdening them.

It seems that the Amelites lived during their feudal rule, even in times of war, in power and strength. No taxes were imposed on them that would burden them, nor were there rulers among them that oppressed them and plundered their money. Rather, these rulers were companions with them, and after the calm and stability of conditions, they proceed to cultivate and exploit their land, without imposing on them tenths, fees, or monopoly. In addition to the above, the accord between the leaders of Jabal Amel was general, and the union between them was tight. And every free leader in his province acted in its affairs, protected its borders, and preserved its entity, and there was no authority above his authority, and no oversight over his actions except the authority of scholars, as for the authority of the Ottoman Sultanate over them was nominal, and it charged them flat fees, and it was not entitled to interfere in the affairs of their country Interior $^{19}$.

The relationship between global feudalism was linked with the Ottoman governors in Palestine, Damascus, and Sidon sometimes with cordiality, and at other times with quarrels, strife, and fighting,

\footnotetext{
13 Tawfiq Muammar, Zahir al-Omar, Nazareth, 1979, p. 9; al-Sabbagh, op. cit, pp. 10-11.

14 Ahmad Ezzat Abdul Karim, "The Administrative Division of Syria in the Ottoman Era", Annals of the Faculty of Arts, Ain Shams University, Vol. 1, May 1951, pp. 134, 173-175.

15 Poliak, Feudalism in Egypt, Syria, Palestine, and Lebanon, trans. by Atef Karam, Beirut, 1948, pp. 137-146.

${ }^{16}$ Cobban (Helena), The Growth of Shi'i Power in Lebanon and its implication for the future. In Juan R. I. Cole and Nikki R. Keddie (ed.), Shi'ism and Social Protest, New Haven and London: Yale University Press, 1986, pp. 138-139.

17 Farhat, op. cit, p. 26.

18 al-Safa, op. cit, pp. 89-90.

19 op. cit, pp. 104-105.
} 
which made the political, military and scientific aspects calm and prosperous in periods of friendliness, turbulent and tense in periods of conflict and strife ${ }^{20}$.

When the Ottomans recognized the influence of the Ma'ni family in Lebanon, the rule of this family did not extend beyond the borders of the Chouf region, except for a limited time. Based on this, we can say: that the feet of Ma'ni did not set foot in the Jabal Amel area, because its residents were able to gain independence in ruling their provinces, as indicated by the incidents that occurred in the villages of Ansar, Nabatiyeh, and Wadi al-Kufuor ${ }^{21}$.

The strength of the inhabitants of Jabal Amel is due to the immunity of their fortresses, and their large number, especially if we add to their strength the strength of their Shiite allies in the regions of the Bekaa', Baalbek and Hermel $^{22}$. The Yemeni Qaisi conflict had an important role in the politics of Jabal Amel after al-Wali Al-Ali al-Saghir people were able to rule Bishara's country at the expense of Al Shukr ${ }^{23}$. al-Amelites Mutawila and the Al-Alam Eddin Druze family represented the Yemeni party, while the Ma'ni and after them the Shehabites headed the Qaisi party ${ }^{24}$.

In $1697 \mathrm{AD}$, the Shihabite family inherited the ruling from the Ma'ni family, so they seized the Jabal Amel provinces from the Al-Ali al-Saghir" family and made them Mahmoud Abi Harmoush, who remained committed to it until he was removed from it by the Governor of Sidon, and he returned it to the Ali al-Saghir family in 1707 AD, but in the following year Prince Haider al-Shihabi was able from the conquest of Jabal Amel, and the victory over the alliance made up of all the leaders of the region in the Battle of Nabatiyeh ${ }^{25}$. Then the Shihabite campaigns on Jabal Amel to subjugate it during the reign of Prince Melhem Haider al-Shihabi, and he was able to achieve several victories over the Amelites in 1731 and $1743 \mathrm{AD}^{26}$.

The Shehabites attacks on Jabal Amel were not intended as mere expansion. Rather, they abide by the covenants they made to the governors of Damascus and Sidon, and that they had to fight for these governors without favor ${ }^{27}$. However, the Amelites did not stand by idly by these attacks. Rather, they prepared for the matter, united among themselves, and concluded treaties with their neighbors; Like what they conducted with Sheik Zahir al-Omar al-Zaidani, ruler of Acre, and the Galilee. After several battles broke out between him and al-Mutawila, he was convinced of the impossibility of joining them by force, just as they felt the necessity of their alliance with him for several reasons, including his strength, his alliance with Ali Bey al-Kabir, Sheik of the Mamluk in Egypt, and his reliance on Russian in opposing the rulers of the Ottoman Sultanate ${ }^{28}$.

\footnotetext{
20 Fayez Tarhini, Sheik Ahmad Reda and the Ameli Thought, presented by Dr. Victor al-Keek, 1 ${ }^{\text {st }}$ Edition, Beirut: Dar al-Afaq Publications, 1983, p. 18.

${ }^{21}$ Abdul Majeed al-Hurr, Landmarks of Ameli Literature, 1 ${ }^{\text {st }}$ Edition, Beirut: Dar al-Afaq al-Jadeeda Publications, 1982, pp. $36-37$.

22 Tarhini, op. cit, p. 19.

${ }^{23}$ Al Shukr: an Amelites family whose lineage is related to Imam Al-Hassan bin Ali, may God be pleased with them, and grew up in the village of A'inatha, south of Jabal Amel, and it is one of the families that ruled the southern country of Bishara for a long time, The al-Wali Al Nassar clan disputed the ruling until Ali al-Saghir was able to destroy them and eliminate their state. al-Safa, op. cit, pp. 42-43.

24 al-Zein, op. cit, p. 264.

${ }^{25}$ Anonymous author, this is the History of Jabal al-Druze and the Levantine and Egyptian Countries, Manuscript in the National Library of Berlin, No. 377 (II) 979 we, folio 4a; Anonymous author, A Walk of Time in the Incidents of Mount Lebanon, Manuscript in the National Library in Paris, No. Arabe 1684, folio 32b.

${ }^{26}$ Anonymous author, The Walk of Time, Folio 35b-36a; Anonymous author, this is The History of Jabal al-Druze, Folio 6b-7a; Constantine Bazile, Syria, and Palestine under Ottoman rule, trans. by: Tariq Ma'sarani, Moscow: House of Progress, 1989 , p. 43.

27 al-Awrah, op. cit, p. 141.

28 Osama Abu Nahel, Zahir al-Omar in Palestine and Ali Bey al-Kabir in Egypt: A Comparative Historical Study, Unpublished MA Thesis, Faculty of Dar Al Uloom, Cairo: Cairo University 1991, pp. 152-158.
} 
The logical result of the Palestinian Amelie Alliance was the success of the forces of this alliance in inflicting a terrible defeat on the army of Prince Yusuf al-Shihabi in 1771 AD in Nabatiyeh when the aforementioned Emir launched a campaign on Jabal Amel, and the consequent fall of the city of Sidon, the capital of the Provence, in the hands of Zahir al-Omar ${ }^{29}$.

Despite this astonishing victory achieved by the said coalition; Amelites abandoned the rescue of Zahir al-Omar twice in $1775 \mathrm{AD}^{30}$, after they felt powerless to face the political and military developments that are summarized in the killing of their ally Ali Bey al-Kabir in $1773 \mathrm{AD}$, the gestures of reconciliation between Turkey and Russia, and the signing of the Treaty of "Kuchk Qinarje" in 1774 AD. ${ }^{31}$

From the above, we see that al-Mutawila give up abandoning their ally, Zahir al-Omar, was not a challenge to him, or a breach of their covenant with him. Rather, it was to preserve their mountain from ruin and loss, after the balance of power changed in the region, and they felt that the Emirate of Zahir alOmar had come to the brink of collapse and fall after it was subjected to several painful blows, whether from within it because of the conflict between Zahir al-Omar and his sons, or because of Ottoman pressure It is increasingly necessary to return Palestine in particular, and the Levant in general, to the direct rule of the Ottoman Sultanate.

What reinforces this view is that after his death, the sons of Zahir al-Omar resorted to the Amelites in the hospitality of Sheikh Nassif al-Nassar to escape from the Ottomans ${ }^{32}$, after the Ottomans appointed Ahmad Pasha al-Jazzar as governor of Acre and Sidon immediately after the killing of Zahir al-Omar. In the new governor's mind, the memory of al-Mutawila's alliance with his predecessor, Zahir al-Omar, in his struggle against the Ottoman Sultan, invoked him to avenge them, but he postponed this task for some time due to his preoccupation with the Bedouins and the Druze, which he considered more urgent at that time $^{33}$.

It seems that al-Mutawila had overcome the dread and fear of al-Jazzar in the late 1780s, and began to launch some attacks on the main roads in the Sidon region, which made al-Jazzar reach his impatience at the end of $1781 \mathrm{AD}^{34}$. So he decided to send his commander, Selim Pasha, to the country of al-Mutawila with an army estimated at three thousand fighters and joined with them in a fierce battle near "Yaroun" in the south of Bishara's country in the same year, which ended with the killing of Sheikh Nassif al-Nassar, the leader of al-Mutawila, along with a number of his followers. al-Jazzar's forces also managed to seize a large number of fortified castles, such as Hunin and Tibnin, in addition to the city of Tire ${ }^{35}$.

Jabal Amel witnessed several uprisings during al-Jazzar era, and its leaders formed a group of revolutionaries called al-Tayah (al-Tawah), which worked to attack al-Jazzar centers, but his response to them was harsh and violent, and it dispersed them ${ }^{36}$. The reason for the failure of these uprisings on the

${ }^{29}$ Bazile, op. cit, pp. 57--58.

30 The first time that Amelites abandoned the aid of their ally, Zahir al-Omar, was during Muhammad Bey's Abu al-Dhahab campaign against Palestine, whose goal was to eliminate the rule of Sheikh Zahir, which forced them to pledge allegiance to Abu al-Dhahab. The second time; It was after the failure of the Abu al-Dhahab campaign, and the advent of the campaign of Hassan Pasha Qubotan, the captain of the Ottoman fleet, who was able to eliminate the emirate of Sheikh Zahir al-Omar and kill him. Abu Nahel, op. cit, pp. 290-292, 300-302.

31 op. cit., Pp. $270,311$.

32 Nicola al-Turk, Incidents of Time in Mount Lebanon, Manuscript in al-Assad National Library in Damascus, No. 4724, Folio 52b53a; Anonymous author, The Story of Ahmad Pasha al-Jazzar, illustrated manuscript, is in the Central Library of Cairo University, No. 22970, Folio 15b-16a.

33 The letter of the French Vice-Consul in Sidon dated 20/8/1776 (ACCM, J-802).

34 The letter of the French Consul in Sidon, dated 10/18/1780, 10/2/1781 AD (Aff. Et. B-1 1038, 1039).

35 al-Turk, op. cit, Folio 63b; The letters of the French Consul in Sidon, dated October 2/1781, June 22, 1782 (Aff. Et. B-1 1039)

36 Ibrahim Baydoun and others, Pages from the History of Jabal Amel, Beirut: Dar Al-Farabi, 1979, pp. 70-71; Ali Sbeiti, "Jabal Amel in two centuries", al-Irfan Journal, Vol. 5, Vol. 1, November 29, 1913, p. 23; Hasan Haidar al-Rukaini, "Jabal Amel in a 
part of al -Mutawila is that they were not organized on the one hand and the absence of a leader with the merits of Sheikh Nassif al-Nassar on the other hand. These uprisings were completely devoid of a revolutionary tendency, or any specific political goal, in addition to having no hesitation in inflicting damage on the people or al-Jazzar's men without distinction between them ${ }^{37}$.

Consequently: The relationship of Amelites al-Mutawila dealer with al-Jazzar passed through some periods of calm and mutual cooperation, but the clash of interests between the two sides led to alienation and the occurrence of the Battle of Yaroun. The repeated al-Mutawila uprisings against al-Jazzar's rule all failed, due to their lack of organization and the absence of a leader to take over them ${ }^{38}$.

\section{Second: the reconciliation between Suleiman Pasha and al-Mutawila and the beginning of the second feudal government}

The defeat of al-Mutawila at the Battle of Yaroun led to the fall of the first feudal government in Jabal Amel, and the weakening of the Amelie federation. The Jabal Amel region was subject to the direct rule of al-Jazzar, at a time when Sheikh Faris bin Sheikh Nassif al-Nassar formed suicide squads, or gangs called "Tayah", to intercept al-Jazzar's soldiers and his workers, and the situation continued like this even after the al-Jazzar's died in $1804 \mathrm{AD}^{39}$.

With the death of al-Jazzar, Lebanon regained its health, its influence, and its control over the political capabilities of al-Sham, which were missing from the time of the rule of Sheikh Zahir al-Omar and Ahmad Pasha al-Jazzar. This influence is due to two main factors: Lebanon's military strength, and the personality of its Emir Bashir II al-Shihabi ${ }^{40}$. With the death of al-Jazzar as well, his Kikhia, Sheikh Taha al-Yazidi, managed to get Ismail Pasha out of the prison in which al-Jazzar put himself, and convinced the statesmen that the butcher, before his death, recommended the appointment of Ismail Mentioned as a governor after him. And the latter subsequently sent consolation books to all provinces and the Muslims over them, so everyone was pleased with the death of al-Jazzar, and the fugitives began to return to their homes ${ }^{41}$.

And when the elders of al-Mutawila were confirmed of the news of the death of al-Jazzar, they came from the country of Akkar to Prince Bashir al-Shihabi to ask for help in restoring their country and their properties. They also sought help from Sheikh Bashir Jumblatt for the same purpose, in exchange for paying the latter half of the rule of the Shomer region in Jebaa' al-Halawa. After the agreement, the people of the Chouf and the Abu Nakad family went out with them, as Prince Bashir wrote to the princes of Hasbaya and Rashaya to go with them with their men, and everyone gathered in Marjeyoun, and as soon as the Ottoman Sultanate knew about the arrival of those crowds, they fled to Tire, so the princes and al-Mutawila moved from Marjeyoun to Hunin Castle and clashed with the state army and were defeated, and they left the aforementioned fortress after suffering heavy losses. Prince Hassan, one of the princes of Wadi al-Taym, was arrested, but Sheikh Taha sent a letter to Prince Bashir apologizing for what happened, justifying that Ismail Pasha was not aware of what had happened ${ }^{42}$.

However, some researchers question the veracity of This novel reported by Haider al-Shihabi, because Sheik Taha al-Yazidi became too weak after the death of al-Jazzar to move an inhabitant without

Century", al-Irfan Journal, Vol. 29, part 1, March 1939, p. 75; Anonymous author, History of Bashir al-Shihabi Family, Manuscript in the National Library in Paris, Arabe No. 2111, Folio 40a.

37 Baydoun and others, op. cit, p. 71.

38 Osama Abu Nahel, Ahmad Pasha al-Jazzar: his administration and his political and economic relations with regional and international powers from 1775-1804 AD. Unpublished Ph.D. thesis, Khartoum: El-Neelain University, 2000, p. 118.

39 al-Safa, op. cit, pp. 98-99.

40 Asad Rostom, Bashir Between Sultan and al-Aziz, Section One, Beirut: Lebanese University Publications, 1956, p.1.

41 Haider al-Shihabi, Lebanon during the reign of the Shihabite princes, comment: Dr. Asad Rustom and Fu'ad Afram al-Bustani, Beirut: The Catholic Press, 1933, pp. 408-409.

42 op. cit, pp. 412-413. 
the knowledge and approval of the military commanders in Acre ${ }^{43}$, and if Sheik Taha was the one who appointed Ismail Pasha, he would not have ordered The latter killed him later, according to what Haider al-Shihabi himself confirmed ${ }^{44}$.

And if all the people were happy and pleased with the death of al-Jazzar, including the sheiks of alMutawila, how do these sheiks - who suffered from al-Jazzar's violence - intend to revolt against the new ruling that secured everyone? Likewise, the elders of al-Mutawila were not in the country of Akkar when they learned of the death of al-Jazzar. Rather, there were two divisions within their country: the first was with al-Tayah, and the other was loyal to the state, such as Sheik Marai's al-Sa'bi.

Haidar al-Shihabi did not name the sheiks of al-Mutawila who sought assistance from Emir Bashir II and Sheikh Bashir Jumblatt by their names, as the Emir of Hasbaya al-Shihabi named after him. Ali alZein whispered to the existence of a conspiracy in which Prince Bashir himself might have been involved in the agreement with Suleiman Pasha - Mamluk of al-Jazzar - who was coveting the rule of Acre, The aforementioned prince disguised the revolution in the name of al-Mutawila - perhaps - in disregard for their feeling and political interests, believing that none of them would dare to go against him, or for fear of his mortgaged sons in Acre since the time of al-Jazzar. And if the sheiks of al-Mutawila are indeed the direct cause of the battle and its heroes, then why did Sheik Taha apologize to Emir Bashir because it was without the knowledge of Ismail Pasha, and it is more appropriate for the Emir himself apologize to the Pasha.

What weakens the structure of Haider al-Shihabi's narration is that the elders of al- Mutawila did not have anything in their possession from the Shomer region, or any of the eight regions of Jabal Amel before Suleiman Pasha assumed power in Acre and Sidon. How, then, can the elders of al-Mutawila be granted what they do not possess or rule (half the rule of the Shomer region, which is in Jibaa') to Sheik Bashir Jumblatt? Taking into consideration that the Shomar region has nothing to do with Jebaa' alHalawa, and the Jebaa' al-Halawa has nothing to do with the Shomer region in both geographical and administrative terms ${ }^{45}$.

Soon, Ismael Pasha was dismissed from his position, and Suleiman Pasha was appointed to rule Acre and the Provence of Sidon on April 1, 1805 AD. The conditions had not calmed down in Jabal Amel when Suleiman Pasha took power. Rather, the guerrilla war expanded, and the authority of the revolutionaries (al-Tayah) extended to include the countries of Acre and Safed, and imposed taxes and fees on the country and killed those who disagreed with them ${ }^{46}$.

The rule of Suleiman Pasha was characterized by justice and fairness, so he was called the just. The narrator of his biography, al-Muallem Ibrahim al-Awrah confirms this, saying; "And when he became firm in his position and assured of his mind, he ordered the launching of the call to safety, security, and justice, and ordered the issuance of preaching orders to all the centers of the province (Sidon), spreading the beacons of justice to all people, and released the imprisoned, and closed the doors of grievances that al-Jazzar had opened it ... as well as Emir Bashir al-Shihabi established himself in the government of Mount Lebanon as a whole, and opened the way for him to safety, and leave so that he could rest his mind, and through it, he was able to secure others, bring escapees, and return the displaced from their countries to their homelands with security and comfort" ${ }^{47}$.

It appears from this text that the view of Sheik Ali al-Zein is correct regarding the existence of some relationship between Suleiman Pasha before he assumes of power and Emir Bashir and that the latter had

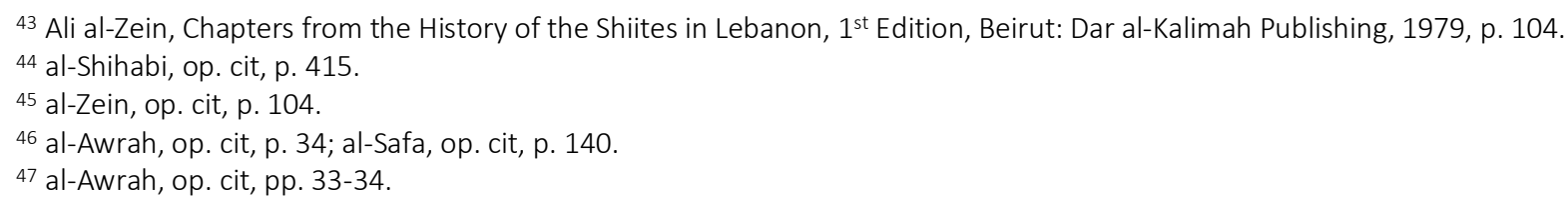


helped and supported him in this tenure. to mediate between him and the rest of the clans who rebel against the rule of the state.

Suleiman Pasha made a treaty with al-Mutawila of Jabal Amel, who had faced severe persecution during the rule of al-Jazzar, after their sheiks, especially Sheik Faris al-Nasif and his brothers, and all the sheiks of the house of Ali al-Saghir, and the sheiks of Bani Munkar and Bani Saab, had secured the grievance that had befallen them before. Historical novels differed about how the peace treaty was concluded between the new ruler and the elite sheiks, which marked the beginning of an era for the second feudal government in Jabal Amel, which lasted until 1831 AD, the year in which Ibrahim Pasha seized the Levant.

Ibrahim al-Awrah, who is close to Suleiman Pasha, says: The latter noticed the misery that befell Jabal Amel and its inhabitants, and the collapse of the country's economic situation, so that the sheiks no longer have a profession from which to live, so he is certain that if things continue in this manner, the region will inevitably reach a total ruin, not only in Jabal Amel but even in the country of Safed, which led him to tend to be soft and calm things down ${ }^{48}$.

According to the result reached by Suleiman Pasha, he sent an Albanian officer called "Bakr Aga alArnaouti" to negotiate with al-Mutawila revolutionaries and agree with them on the terms of reconciliation and surrender, so they refused to negotiate with him for fear of treachery and deceit. Noting that they were eager to obtain safety from the governor, but the harsh and terrifying conditions that they had witnessed during the era of al-Jazzar led them to refuse to negotiate with Bakr Agha. To respond to their demands, and since the aforementioned Emir is considered the leader of all Lebanese tribes, including the Mutawila, he agreed to mediate in this case.

Al-Mutawila, in turn, accepted the idea of Prince Bashir's mediation between them and the governor, because - according to what Ibrahim al-Awrah reported - they could not rely on anyone but him, as well as his clear jealousy on the sons of the tribes. Indeed; Prince Bashir interfered in the matter of reconciliation between the two parties and tried several times to improve the terms of reconciliation in favor of the client, which angered the governor. Whatever the case; All the parties managed to formulate the terms of the peace agreement, which was approved by Suleiman Pasha himself, as well as Raghib Effendi, the commissioner of the High Porte.

The conditions for reconciliation are as follows:

1. A general amnesty for all revolutionaries.

2. Al-Mutawila will participate in the minister's wars later, whenever necessary, and to attend without hesitation.

3. The elders of al-Mutawila give the Shomer region property for them and their descendants divided equally instead of their properties seized by the state, except the villages of Sarafand, Ansar, and Mays, exempt from taxes and princely funds. And for everyone to sign a special notebook for that, to confirm that the distribution process has been completed with their consent and agreement, so that no dispute will arise in the future.

4. State employees should not have any interference in the governance of the country, nor authority over its sheiks, but rather refer the sheiks in their affairs, and the separation of the dispute that occurs between them is to the sheik of sheiks, Faris al-Nassif, who represents them before the government, and for him the responsibility reverts.

Whatever the case; Sheik Faris al-Nassif arrived in Acre, heading the delegation of the Amelites clans, and met the governor, Suleiman Pasha, with great honor, care, and hospitality, and it was signed in the presence of the judge of Acre and its mufti, Raghib Effendi, the chief rulers in Acre, and Sheik Gerges

48 op. cit, pp. 34-37. 
Baz, an agent of Emir Bashir. For Suleiman Pasha to show his satisfaction with Sheik Fares al-Nassif, he gave him a luxurious dress of sable fur, in addition to five thousand piasters, ten bags of wheat, and twenty barley.

From the context of what Ibrahim al-Awrah reported, several things worth noting, including alMutawila Sheiks were not the first or the first to seek reconciliation with Suleiman Pasha. Rather, the latter is the one who was keenly on the arrival of the sheiks and securing them by any means, to relieve the servants from their evil and harm, and to live the state agrees with them, and if this is the goal of the pasha, then it is verifiable not to think of removing them from the rule of their country or imposing unfair conditions on them. Those conditions that were assumed by the disinterested messengers of Emir Bashir, then historians fabricated their background and reasoning so that in the view of the ordinary reader they become necessary and natural ${ }^{49}$.

Ali Sbeiti confirms the validity of what Ali al-Zain concluded by saying: "Until the year $1219 \mathrm{AH}$, al-Jazzar perished and was succeeded by Selim Pasha, (Meaning Ismail Pasha), one of the Mamluks. Then the soldiers turned against him and killed him, and set up Suleiman Pasha ... and kept the Jew Haim Farhi, and overpowered his command, Ali Pasha. Their first order was that they approached the tribes, placated them, compensated them for their usurped property that he had usurped (i.e., al-Jazzar), and brought them back to their homelands after displacement. Thus, the country rested from their corruption during the days of their displacement, and from the corruption of al-Jazzar's soldiers ..." ${ }^{50}$. That is, Suleiman Pasha was the one who first sought to appease the elders of al-Mutawila, and compensates them for the property that al-Jazzar confiscated from them.

Moreover, the elders of al-Mutawila, if they had previously listened to Bakr Agha's suggestions, would have achieved better results than they achieved later after they were imposed and exploited by Emir Bashir to eliminate their influence and encircle them politically, economically, and militarily with heavy restrictions, as he used them to approach the pasha and gain his approval and appreciation. Ali al-Zain believes that Emir Bashir's petitions regarding al-Mutawila sheiks were not devoid of deception and deceit and that the Pasha's anger at him was not real, but rather a kind of artificiality and representation whose victim was the sheiks themselves who had to be intransigent in their demands, and not to respond to any of the conditions, or to participate in any war with the pasha or Emir Bashir until after answering their original demands, and their argument would have been that they could not impose their will on the handler, as long as their country was ruled by others, and they had no official authority over its people, and they had no revenues that would help them bear the expenses of some of the supposed conditions. Like the obligation to pay the expenses of two thousand men and horsemen annually, they are prepared for war with the state whenever called for.

Ali al-Zein demonstrates the conspiracy of Emir Bashir and Suleiman Pasha against the elders of alMutawila, that the officer Bakr Agha, when he presented to the aforementioned sheiks, the idea of pardon and safety from the pasha, he did not think of any of these unfair conditions imposed on these sheiks later, on, rather he was only thinking about what The pasha himself would think of him, of bringing the sheiks and reassuring them by any means that they would be satisfied with. The idea of the sheiks 'handing out of ruling their country was not on the mind of the pasha, nor in the mind of Bakr Agha before Emir Bashir and his entourage intervened to plan the plot and convince the sheiks of it ${ }^{51}$.

Perhaps the disagreement that took place between the Sheiks of al-Mutawila - especially between the sons of Nassif al-Nassar, who each tried to please Suleiman Pasha at the expense of his brother - had a role that helped Emir Bashir and his directors to play their game in seeking to stop the hands of the sheiks

\footnotetext{
49 op. cit, pp. 37-48.

50 Sbeiti, op. cit, p. 24.

51 al-Zein, op. cit, pp. 120-125.
} 
from ruling their country, restricting them to these unfair conditions, and then restricting them Within the villages of al-Shomer region, as evidenced by the terms of reconciliation and its annexes ${ }^{52}$.

It seems that Bakr Agha tried, after the conclusion of the reconciliation, to cause a dispute between the elders of al-Mutawila and Suleiman Pasha, and he began to improve for the sheiks the idea of giving them the Muslims of the whole country, not just al-Shomer region, and although some of them began to accept what he said, his attempt was unsuccessful and he was expelled from military service ${ }^{53}$.

The living conditions improved in Jabal Amel during the reign of Suleiman Pasha, as confirmed by historians, and in this Sheik Ali Sbeiti says: "... and the situation calmed down during the days of Suleiman Pasha, and the country went over and overgrown, and the buildings were over-built, and trees were planted, and his treatment was Good until he died ..." ${ }^{54}$. Indeed; Suleiman Pasha rebuilt the Zahrani River Bridge on the seashore between Tire and Sidon in 1811 A.D. He also renewed the reconstruction of the Sea Castle in Sidon in 1813 A.D., and repaired the Nawakeer Road in the years 1812-1813 AD, which is the road linking Tire and Acre at the Naqoura region, and so on. Reforms ${ }^{55}$.

Meanwhile, the Wahhabis in the Arabian Peninsula had taken possession of Hijaz and began to prepare to attack and seize the borders of the Levant ${ }^{56}$, after they prevented the arrival of the Levantine pilgrimage convoy in 1807-1808 AD to the Holy Land, and it was headed by Abdullah Pasha al-Azm, the last of an al-Azm family ${ }^{57}$. The impact of the shock was strong on Istanbul after the severe embarrassment to which the Ottoman Sultanate was subjected, and its feeling of insult to prevent the caravan of pilgrims from reaching Hijaz to perform the Hajj ${ }^{58}$.

Sultan Mahmoud assigned the new governor of the Levant Yusuf Kanj Pasha to go to fight the Wahhabis in Hijaz itself, but he was unable to implement the campaign, which embarrassed his position in front of the High Porte ${ }^{59}$. For Yusuf Pasha to defend the southern provinces of his state against the Wahhabi tide, he built several military observation posts in Houran and concentrated his forces there, as well as strengthened the castles in al-Muzayrib area. Yusuf Pasha did not aspire to conduct an antiWahhabi attack; Rather, he only tried to defend Damascus. It seems that the new governor was somewhat realistic, because the problem of the Wahhabis was intractable and was greater than his capabilities, and he could not solve it on his own due to the challenges facing his authority within the state ${ }^{60}$. Among the most important of these is his disagreement with the Governor of Acre and Sidon, Suleiman Pasha, and his tense relationship with Emir Bashir al-Shihabi, Prince of Mount Lebanon ${ }^{61}$. Yusef Pasha found that it would be more appropriate to coordinate with the governors of Egypt, the Levant, and Baghdad, their military plans, by sending three campaigns from different sides simultaneously, opening up to the Wahhabis multiple fronts that are far apart ${ }^{62}$.

\footnotetext{
52 al-Zein, op. cit, pp. 125-129.

53 al-Awrah, op. cit, pp. 48--52.

54 Sbeiti, op. cit, p. 24

55 al-Awrah, op. cit, pp. 180, 200--204.

56 op. cit, pp. 98-99.

57 al-Shihabi, op. cit, p. 512; Muhammad Diaa al-Din al-Rayes, The Arab East and the Ottoman Caliphate, Vol. 1, Cairo: The Renaissance Library of Egypt, 1950, p. 217; Koury (George John), The Province of Damascus, 1783-1832, Ph.D. Dissertation, The University of Michigan, 1970, p. 131.

58 Rustom, op. cit, p. 27; Holt (P.M.), Egypt and the Fertile Crescent 1516-1922, New York: Cornell University Press, 1966, p. 233.

59 al-Rayes, op. cit, p. 217.

60 Koury, op. cit, p. 131.

61 al-Awrah, op. cit, p. 98; Rustom, op. cit, p. 29.

62 Jamal Zakaria Qassem and others, The Lebanese Crisis: Its Origins, Development, and Its Various Dimensions, Cairo: Published by the Arab Organization for Education, Culture and Science, 1978, p. 54.
} 
Whatever the case; The star of Yusuf Pasha began to diminish because of his inability to divest the campaign against the Wahhabis, while the star of Suleiman Pasha was on a continuous rise after he sent food aid and crops to Astana due to the drought that had descended there, and he won to his class the ruling men in the Ottoman Sultanate ${ }^{63}$.

The Wahhabis came to Horan in $1810 \mathrm{AD}$, ate green and dry land, burned villages, and enchanted women and children ${ }^{64}$, so Yusef Pasha was forced to seek help from Suleiman Pasha under the justifications of serving the religion and the state, so he fulfilled his request and walked to him with his army. Suleiman Pasha also instructed Emir Bashir to gather the men he could, and meet him in Tiberias to march together to Muzayrib, where the Emir was already able to mobilize fifteen thousand fighters ${ }^{65}$. It should be noted the participation of the elders al-Mutawila in this campaign, after Suleiman Pasha wrote a decree to Sheik Faris al-Nassif, the sheik of the elders of al-Mutawila, ordering him to gather the men of the tribes under his influence and attend with them to Tiberias, which he arrived with Emir Bashir alShihabi ${ }^{66}$.

Just before Suleiman Pasha left Acre on his way to Tiberias, an Ottoman commissioner arrived and handed him a firman appointing him as governor of Damascus and Tripoli, and dismissing Yusef Pasha. Farman cited by saying: Yusuf Pasha was dismissed for not being able to lead the pilgrims' caravan, and for postponing the leadership of the campaign against the Wahhabis ${ }^{67}$.

It seems that Suleiman Pasha - who was concerned with responding to the Wahhabi threat from the Levant - is not much different from his previous governors of Sidon, who were looking to rule the Provence of Damascus by any means possible. That is why his preparations were not serious to support Yusuf Pasha Kanj's humble efforts against the Wahhabis ${ }^{68}$.

Meanwhile, Yusef Pasha - who was not aware of the previous firman - had arrived at Houran to help Shamdeen Agha, the surrender of Irbid and Ajlun, who was besieged in al-Muzayrib castle ${ }^{69}$, and arrived on time after it was about to fall into the hands of the Wahhabis, and he began to fire his artillery to terrorize them, so they were forced to flee And retreat ${ }^{70}$.

After Suleiman Pasha and Emir Bashir learned of the desertion of the Wahhabis, they decided to implement what was mentioned in the Royal firman and decided to attack Damascus by force, taking advantage of the opportunity of Yusuf Pasha's presence outside it, who later learned of Suleiman Pasha's intention, so he left al-Muzayrib and returned to Damascus to arrange his matter on how to confront his new enemy ${ }^{71}$.

Suleiman Pasha and Prince Bashir accompanied their soldiers and were accompanied by the masses of al-Mutawila to Damascus on the Quneitra-Daraya road, and upon their arrival at Qatana they learned of the return of Yusef Pasha to Damascus, and they sent to the notables of Damascus informing them of the royal firman that required the dismissal of Yusef Kanj Pasha and they gave them a three-day period to respond, after the expiration of that deadline They marched to al-Jadida and Daraya and clashed with

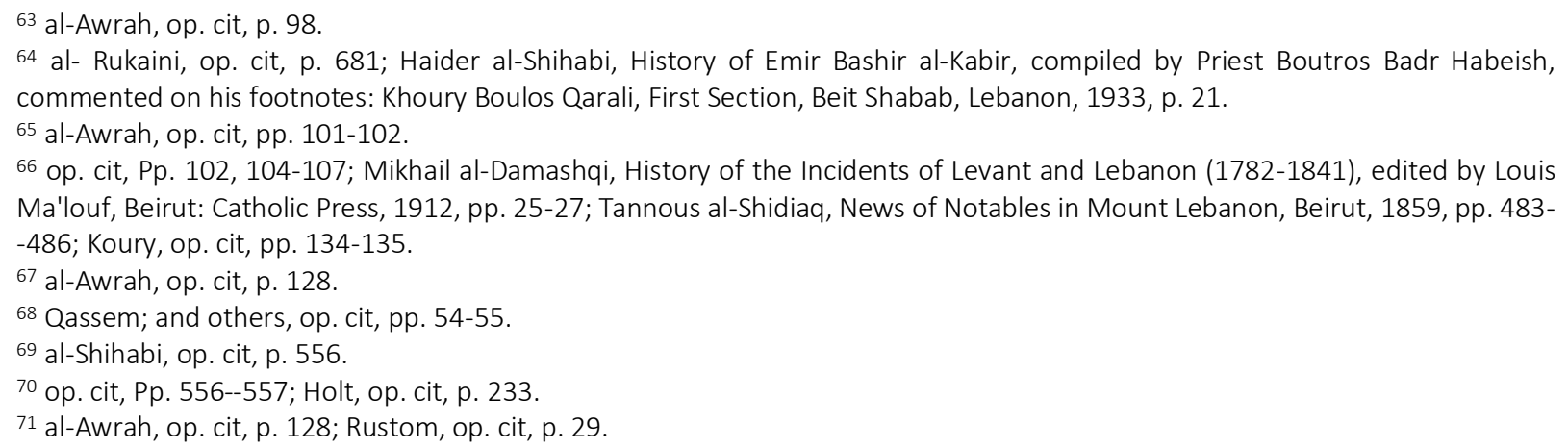


the Damascene army, and Yusuf Pasha failed to repel them, so he was forced to flee to Egypt, seeking asylum from its governor, Muhammad Ali Pasha. The victors entered Damascus, and Suleiman Pasha was appointed as its governor, in addition to Tripoli and Sidon ${ }^{72}$.

And what is evidenced by the help of the sheiks of al-Mutawila of Suleiman Pasha and Emir Bashir in their war with Yusuf Pasha is what one of the Amelites historians said: "At the end of the month, Suleiman Pasha came to the Levant with the Druze (the assistants of Emir Bashir) and al-Mutawila, and a battle broke out between him and Yusuf Pasha, and victory was to Suleiman Pasha, Ahmad Ibn Abbas al-Muhammad from al-Mutawila was killed, along with two brothers of the sons of Mitrik, and Yusuf Pasha was defeated and Suleiman Pasha returned to the Levant ${ }^{73 "}$.

Al-Mutawila sheiks believed that the services they provided to Suleiman Pasha, and their standing by him in his war with Yusuf Pasha, would qualify them to ask him to grant them the entire government of Jabal Amel, not just al-Shomer region. Most of these sheiks approached Emir Bashir al-Shihabi and Sheik Bashir Jumblatt, as they took the Emir and managed his affairs, and asked them to persuade the Pasha to return all their possessions to them. Emir Bashir tried to persuade the Pasha of the request of the aforementioned sheiks several times without success, to the point where the relationship between the two parties worsened. The tension between the two parties reached a level that reached the point of threat, and the Pasha responded to Emir Bashir, saying: "As I did not benefit with you all that I used towards you, do what you want and you are authorized to agree with the sheiks of al-Mutawila, and do with them what you want, and I am ready for every matter that comes. Perjury, so he breaks himself" ${ }^{74}$.

It seems that Emir Bashir regretted his interference in this case, and he feared for himself and the sheiks of al-Mutawila from the wrath of the pasha. As for the elders of al-Mutawila, they were no longer able to re-request this throughout the life of Suleiman Pasha, and until he died in $1818 \mathrm{AD}^{75}$.

It is evident from what has been previously explained as something of an exaggeration, it is unreasonable that Emir Bashir put his political future at risk to satisfy the sheiks of al-Mutawila. It was sufficient for the Emir to petition Suleiman Pasha to grant these sheiks all their properties only once, but the writer repeated the Emir's review of the Pasha in this regard several times, as if Emir Bashir was anxious about the supreme interest of al-Mutawila, or that his political future is contingent on them.

What counts for Suleiman Pasha - two years before his death - is that he ordered the isolation of Ibrahim Agha al-Kurdi from Bishara's country, because of what he and the Kurds imposed on the peasants in terms of excessive fines, so that they made the peasants their slaves ${ }^{76}$.

\section{Third: the evolution of al-Mutawila's relationship with Abdullah Pasha}

Suleiman Pasha was succeeded by Abdullah Pasha Ibn Ali Pasha in 1819 AD, and he is also one of the Mamluks of al-Jazzar ${ }^{77}$, and Suleiman Pasha's stepson and son-in-law. The people had mercy on alJazzar and forgot his injustice, because of the unfairness and arbitrariness of Abdullah Pasha. ${ }^{78}$

Despite the violence that Abdullah Pasha wore with the residents of his Provence, his relationship with Amelites al-Mutawila appears to have been at its best. In 1821 AD, Abdullah Pasha wrote to Sheik Faris al-Nassif and the rest of the Sheiks of al-Mutawila, with his desire to restore the rule of Jabal Amel to them (that is, Bilad al-Shomer and Bilad al-Shuqif), He also wrote to them about his desire to raise the

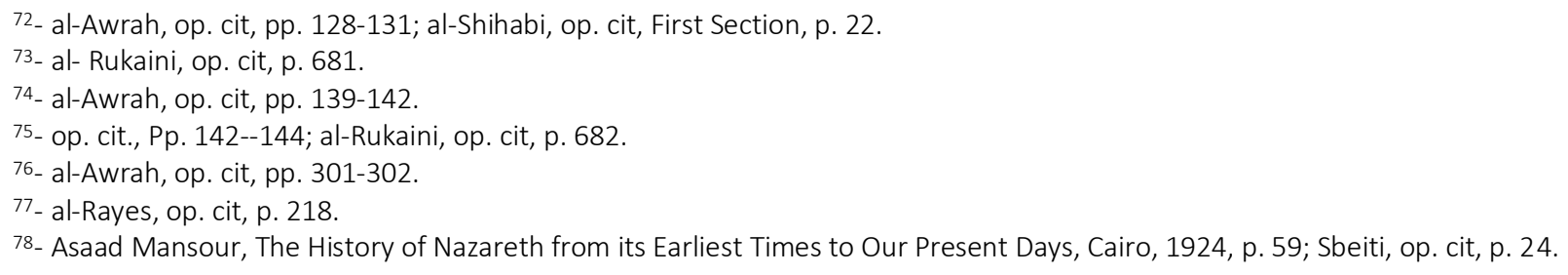


Mutaslims from it, and that he intends to form a bond in it whose mission is to supply the Amiri funds, as was the case in the time of the Mutaslims who were appointed by the pasha. And he made it clear to them that he would leave them fifty thousand piasters every year, and a hundred bag of barley, provided that they had two thousand imaginations and fighters who would be under his command whenever he needed them $^{79}$, as Haider al-Shihabi asserts.

Al-Mutawila Sheiks refused this offer at first because they feared treachery, and after several consultations, he sent them in consultation with Emir Bashir al-Shihabi, who indicated to them that the governor, Abdullah Pasha, is in dire need of their efforts, given the tension in his relationship with the governor of Damascus, Darwish Pasha, and he made it clear to them that it is in their interest to restore Ruling their country as it was in the past. Whatever the case; Abdullah Pasha wrote to Sheik Faris alNassif and the sheiks of al-Mutawila, a document to restore the rule of Jabal Amel for them. And these sheiks began to take an interest in managing horses, weapons, and fighters from their countries, according to what the pasha ordered them to do. Not to mention that the pasha also granted them the region of Marjeyoun, and imposed on them money known, as was the situation during the time of the Mutaslims before them ${ }^{80}$.

Hassan Haidar al-Rukaini, the Amelie historian, says: "And in it (meaning the year $1237 \mathrm{AH}$ ) in the month of Jumada al-Awwal, Abdullah Pasha was pleased with al-Mutawila and brought them back to their places" $"$.

If we compare the novels of Hasan Haidar al-Rukaini and Haidar al-Shihabi, we will notice that alRukaini intended to return al-Mutawila to their places in the rule of their country, which they were deprived of during the reign of al-Jazzar and Suleiman Pasha after him. Despite the abbreviation of the phrase al-Rukaini, it is truer than Emir Haider al-Shihabi, with his elaboration and mention of unjustified matters. There was no disagreement between the Sheikhs of al-Mutawila and Abdullah Pasha, and there was no justification for reasons of caution and fear of him, as was their case with al-Jazzar and Suleiman Pasha. Thus: There is no need for these sheiks to resort to the advice of Emir Bashir, as mentioned by Haider al-Shihabi.

To make matters clearer, it was the pasha himself who offered to return to what they were in without the need for the mediation of a third party. Haidar al-Shihabi did not intend from behind this except to make the illusion that al-Mutawila was nothing but followers of Emir Bashir, who would not take a step without his advice, or so to speak - minors (short-sighted in political affairs). About the condition that Abdullah Pasha stipulated that two thousand fighters should be arranged, they are ready to assist him in any war in which he participates whenever he calls them to it,

It is not a new thing, nor a heresy that Abdullah Pasha invented. So, Suleiman Pasha - before stipulated the same thing on them, with a fundamental difference that Suleiman did not return them to the rule of their entire country and did not compensate them with anything from the additional expenses, unlike what Abdullah Pasha did with them. Not to mention that Abdullah Pasha was at that time in dire need of al-Mutawila services, especially since the political atmosphere between him and Darwish Pasha, the governor of Damascus, smelled the smell of gunpowder.

In summary: The peace agreement that had been concluded in the past between the elders of alMutawila and Suleiman Pasha was amended during the reign of Abdullah Pasha in favor of these sheiks, which led to the further consolidation of the political independence of the Jabal Amel administration during the reign of Abdullah Pasha.

\footnotetext{
79 al-Shihabi, History of Emir Haider, vol. 4, p. 1247.

80 op. cit, Pp. 1247-1248.

81 al- Rukaini, op. cit, p. 682.
} 
In any case, Abdullah Pasha's policy towards al-Mutawila paid off; In the same year, i.e. in Rajab $1237 \mathrm{AH} / 1821 \mathrm{AD}$, the conflict intensified between him and Darwish Pasha, the governor of Damascus, and Abdullah Pasha was able to win over some of the sheiks of Nablus, which led to a division between the people of that country, so they divided into two groups that fought each other, so Darwish was forced Pasha to send his deputy, Vizo Pasha, with the military to Nablus. When Abdullah Pasha knew about the arrival of Vizo Pasha to al-Muzayrib desert, he sent his forces, including the soldiers of al-Mutawila, led by Sheik Faris al-Nassif, and the Emir Bashir al-Shihabi to the Banat Yacoub Bridge and the Majma' 'Bridge, to prevent Darwish Pasha's forces from crossing. A battle took place at the Banat Yacoub Bridge, which ended with the defeat of the Damascus forces, and the capture of Abdullah Pasha's army of the defeated weapons, cannons, and ammunition, in addition to many prisoners, and many deaths among them ${ }^{82}$.

Hasan Haidar al-Rukaini confirms the validity of al-Mutawila's participation in this battle, saying: "In the month of Rajab (1237 AH), a battle took place between Abdullah Pasha and the Pasha of al-Sham Darwish Pasha on the Banat Yacoub Bridge. The soldiers of the Pasha of the Levant were defeated in it, and they took mortars and cannons from him, and they were al-Mutawila with Abdullah Pasha"83. Sheik Ali Sbeiti also confirmed the participation of al-Mutawila in the battle of Banat Yacoub Bridge, but he made the battle in $1236 \mathrm{AH}^{84}$.

Matters worsened between the two ministers and worsened after Darwish Pasha sent a letter to Emir Bashir al-Shihabi informing him that the Ottoman Sultanate blessed him with the Provinces of Sidon, Jaffa, Tripoli and the rest of the provinces in the hands of Abdullah Pasha, in addition to his current position as governor of Damascus, but Emir Bashir did not reply to Darwish Pasha, Then Emir Bashir sent the aforementioned book to Abdullah Pasha, who ordered him to gather more Lebanese people and walk to the Banat Yacoub Bridge. And in blatant defiance of Abdullah Pasha, the governor of Damascus, his signature wrote thus: "Mister Abdullah Pasha, the Emir of Hajj, and the governor of Damascus, Sidon, Jaffa, and Tripoli al-Sham immediately". This means, in the final analysis, that Abdullah Pasha is determined to put an end to Darwish Pasha's political future and to isolate him from the rule of Damascus by force.

Emir Bashir tried to dissuade Abdullah Pasha from attacking Damascus, because, as he put it, "the door of the Kaaba", meaning the place where the Levantine Hajj gathered on his way to the Hijaz, and he arrived in Acre to meet him on May 15, $1821 \mathrm{AD}$, in an attempt to persuade him to deviate from his plan But, the hospitality that the Emir received and the precious gifts that were presented to him, made him change his mind and go out himself to the Banat Yacoub Bridge. Abdullah Pasha's forces and his allies continued their march towards Damascus, prompting Darwish Pasha to go out to "al-Mazzeh" - relative to the town in which the fighting took place - to fortify it, in preparation for the siege imposed shortly by the people of Acre and the Lebanese Druze and Shiites (al-Mutawila). A fierce battle was fought, which ended with the defeat of the soldiers of the Levant and the burning of al-Mazzeh, and the killing of many of them, in addition to the fall of many prisoners and spoils ${ }^{85}$.

Darwish Pasha was forced to seek refuge in the Citadel of Damascus, and the people of Damascus and its villages in the city took refuge in the city and built the barricades ${ }^{86}$, but soon the people gave up and Damascus became subject to the influence of Abdullah Pasha after Darwish Pasha left it ${ }^{87}$. And when the Ottoman Sultanate found that Abdullah Pasha had become the most powerful man in the Levant and

\footnotetext{
82 al-Shihabi, op. cit, vol. 4, pp. 1251-1252.

83 al- Rukaini, op. cit, p. 683.

84 Sbeiti, op. cit, p. 24.

85 al-Shihabi, op. cit, pp. 1252-1254.

86 al- Rukaini, op. cit, p. 683.

87 Sbeiti, op. cit, p. 24.
} 
could not be defeated, it was forced to recognize him, annexed the province of Damascus, and expanded his possession. ${ }^{88}$

The Ottoman Sultanate used to appoint Shiite judges in the eight provinces of Jabal Amel under the name of the deputy, during the days of tribal rule. During the reign of Abdullah Pasha, Sheik Saeed al-Jar Al-Jabae was appointed as a deputy of Jaba' by a decree dated 1824 AD, and his son Sheik Hassan Saeed was deputy for the judge of Sidon in Jaba' district ${ }^{89}$.

During the period from 1824 AD, and until the Egyptians seized the Levant in 1831-1832 AD, historical sources did not report any news about Jabal Amel, and it seems that negligence in mentioning this news was not intentional, because there were no significant events that passed through Jabal Amel during that period.

\section{Conclusion}

It is possible to record a number of the results of the study, including:

- That Amelie Ottoman relations were strained as a result of the Amelites affiliation to the Shi' ite sect to which the Safavid rulers of Iran also belonged. It seems that, as a direct response to the Ottoman-Safavid differences, its effects had reverberated on the Shiites of Jabal Amel throughout Ottoman rule over the Levant.

- The new governor of Acre and Sidon, Suleiman Pasha, was forced to conclude a peace treaty with Amelites, as a result of the increasing attacks of their revolutionaries against the Ottoman Sultanate's soldiers, regardless of the role of Emir Bashir II al-Shihabi in completing this peace, as some historians tried to make of the Amelites submissive followers of Emir Bashir Guided by his advice. This is a completely different picture of what al-Mutawila sheiks used to do to some extent alone in their political decision so that when they allied with Sheik Zahir Al-Omar before, they had their political decision independent of him.

- Al- Mutawila Sheiks participated in the wars of the Ottoman Sultanate in some periods to repel the Wahhabi tide that threatened the borders of the Levant, and their assistance to Suleiman Pasha in his war against the governor of Damascus, Yusuf Kanj Pasha, to obtain the mandate of Damascus itself.

- Al-Mutawila's relationship with Abdullah Pasha, behind Suleiman Pasha, developed and improved after he agreed to grant them more of their property that al-Jazzar had previously confiscated, which led to the further consolidation of their political independence in Jabal Amel.

88 al-Rayes, op. cit, p. 218.

89 al-Amin, op. cit, pp. 135-136. 


\section{References}

\section{First: the manuscripts}

\section{A. Correspondence of the French consuls accredited in Sidon}

The correspondence of these consuls is of great importance due to the contemporaries of their writers of historical events, which are documents of historical value, which are in the possession of the French Ministry of Culture (Historic Center of National Archives), Ministre Culture, Center Historique, de Archivés Nationales, CARAN, Paris).

The documents or correspondence bearing ACCM means the archive of the Marseille Chamber of Commerce (Archivé de Chambre de Commerce et d'industrie de Marseille).

As for documents or correspondence bearing symbols (AFF. ET); It means the correspondence of foreign affairs in the National Archives in Paris (Les Achieves Nationales, Paris).

And its statement is as follows:

$($ ACCM, J-802 = Seyde).

(AFF. ET. B1 $1038=$ Seyde).

(AFF. ET. B1 $1039=$ Seyde).

\section{B. Arabic manuscripts}

Al-Turk (Nicola), Incidents of Time in Mount Lebanon, Manuscript in al-Assad National Library in Damascus, No. 4724.

Anonymous author, A Walk of Time in the Incidents of Mount Lebanon, Manuscript in the National Library in Paris, No. Arabe 1684.

Anonymous author, History of Bashir al-Shihabi Family, Manuscript in the National Library in Paris, Arabe No. 2111.

Anonymous author, The Story of Ahmad Pasha al-Jazzar, illustrated manuscript, is in the Central Library of Cairo University, No. 22970.

Anonymous author, This is the History of Jabal al-Druze and the Levantine and Egyptian Countries, Manuscript in the National Library of Berlin, No. 377 (II) 979 we.

Second: Arabic and translated references

Abu Nahel (Osama), Ahmad Pasha al-Jazzar: his administration and his political and economic relations with regional and international powers from 1775-1804 AD. Unpublished Ph.D. thesis, Khartoum: El-Neelain University, 2000.

Abu Nahel (Osama), Zahir al-Omar in Palestine, and Ali Bey al-Kabir in Egypt: A Comparative Historical Study, Unpublished MA Thesis, Faculty of Dar Al Uloom, Cairo: Cairo University 1991.

Abdul Karim (Ahmad Ezzat), "The Administrative Division of Syria in the Ottoman Era", Annals of the Faculty of Arts, Ain Shams University, Vol. 1, May 1951.

Al-Amin (Mohsen), Jabal Amel Plans, $1^{\text {st }}$ Edition, Edited by Hassan Al-Amin, Beirut: The International House for Printing, Publishing, and Distribution, 1983.

Al-Damashqi (Mikhail), History of the Incidents of Levant and Lebanon (1782-1841), edited by Louis Ma'louf, Beirut: Catholic Press, 1912. 
Al-Hurr (Abdul Majeed), Landmarks of Ameli Literature, $1^{\text {st }}$ Edition, Beirut: Dar Al-Afaq Al-Jadeeda Publications, 1982.

Ali (Muhammad Kurd), Khotat al-Sham, Vol. 6, Damascus, 1925.

Al-Rayes (Muhammad Diaa al-Din), The Arab East and the Ottoman Caliphate, Vol. 1, Cairo: The Renaissance Library of Egypt, 1950.

Al-Rukaini (Hasan Haidar), “Jabal Amel in a Century”, al-Irfan Journal, Vol. 29, part 1, March 1939.

Al-Sabbagh (Mikhail), The History of Sheikh Zahir al-Omar al-Zaidani, published and commented: Constantine al-Basha al-Mukhlesi, Harissa, 1935.

Al-Safa (Muhammad Jaber), History of Jabal Amel, $2^{\text {nd }}$ Edition, Beirut: An-Nahar Publishing House, 1981.

Al-Shihabi (Haider), History of Emir Bashir al-Kabir, compiled by Priest Boutros Badr Habeish, commented on his footnotes: Khoury Boulos Qarali, First Section, Beit Shabab, Lebanon, 1933.

Al-Shihabi (Haider), Lebanon during the reign of the Shihabite princes, comment: Dr. Asad Rustom and Fu'ad Afram al-Bustani, Beirut: The Catholic Press, 1933.

Ibrahim Al-Awrah, History of the Wilayat of Suleiman Pasha al-Adil, published and commented on: Constantine al-Basha al-Mukhlesi, Sidon, 1936.

Al-Zein (Ali), Chapters from the History of the Shiites in Lebanon, $1^{\text {st }}$ Edition, Beirut: Dar al-Kalimah Publishing, 1979.

Al-Zein (Ali), In Search of Our History in Lebanon, $1^{\text {st }}$ Edition, Beirut, 1973.

Anonymous author, the disclosure of the Nakbat al-Sham, $1^{\text {st }}$ Edition, Cairo, 1895.

Bazile (Constantine), Syria and Palestine under Ottoman rule, trans. by: Tariq Ma'sarani, Moscow: House of Progress, 1989.

Baydoun (Ibrahim) and others, Pages from the History of Jabal Amel, Beirut: Dar Al-Farabi, 1979.

Farhat (Hani), The Ameli Trio in the Renaissance, Beirut: The International House of Printing, Publishing, and Distribution, 1981.

Makki (Muhammad Kazim), Intellectual and Literary Movements in Jabal Amel, $2^{\text {nd }}$ Edition, Beirut: Dar al-Andalus for Printing, Publishing, and Distribution, 1982.

Mansour (Asaad), The History of Nazareth from its Earliest Times to Our Present Days, Cairo, 1924.

Muammar (Tawfiq), Zahir al-Omar, Nazareth, 1979.

Qassem (Jamal Zakaria) And others, The Lebanese Crisis: Its Origins, Development, and Its Various Dimensions, Cairo: Published by the Arab Organization for Education, Culture and Science, 1978.

Poliak, Feudalism in Egypt, Syria, Palestine, and Lebanon, trans. by Atef Karam, Beirut, 1948.

Rostom (Asad), Bashir Between Sultan and al-Aziz, Section One, Beirut: Lebanese University Publications, 1956.

Sbeiti (Ali,) “Jabal Amel in two centuries”, al-Irfan Journal, Vol. 5, Vol. 1, November 29, 1913.

Tarhini (Fayez), Sheikh Ahmad Reda and the Ameli Thought, presented by Dr. Victor al-Keek, $1^{\text {st }}$ Edition, Beirut: Dar Al-Afaq Publications, 1983.

Third: Foreign References 
Charles - Roux (F.), Les Echelles des Syrie et de Palestine au XV III Siècles, Paris, 1928.

Cobban (Helena), The Growth of Shi'i Power in Lebanon and its implication for the future. In Juan R. I. Cole and Nikki R. Keddie (ed.), Shi'ism and Social Protest, New Haven and London: Yale University Press, 1986.

Holt (P.M.), Egypt and the Fertile Crescent 1516-1922, New York: Cornell University Press, 1966.

Koury (George John), The Province of Damascus, 1783-1832, Ph.D. Dissertation, The University of Michigan, 1970.

Lammens (S.J.), La Syrie Précis Historique, Vol. 2, Beyrouth, 1921. 